Louisiana State University

LSU Digital Commons

$4-1-2012$

\title{
Trehalose transporter from African chironomid larvae improves desiccation tolerance of Chinese hamster ovary cells
}

\author{
Nilay Chakraborty \\ Harvard Medical School \\ Michael A. Menze \\ Eastern Illinois University \\ Heidi Elmoazzen \\ Harvard Medical School \\ Halong $\mathrm{Vu}$ \\ Harvard Medical School \\ Martin L. Yarmush \\ Harvard Medical School
}

See next page for additional authors

Follow this and additional works at: https://digitalcommons.Isu.edu/biosci_pubs

\begin{abstract}
Recommended Citation
Chakraborty, N., Menze, M., Elmoazzen, H., Vu, H., Yarmush, M., Hand, S., \& Toner, M. (2012). Trehalose transporter from African chironomid larvae improves desiccation tolerance of Chinese hamster ovary cells. Cryobiology, 64 (2), 91-96. https://doi.org/10.1016/j.cryobiol.2011.11.007
\end{abstract}

This Article is brought to you for free and open access by the Department of Biological Sciences at LSU Digital Commons. It has been accepted for inclusion in Faculty Publications by an authorized administrator of LSU Digital Commons. For more information, please contact ir@lsu.edu. 


\section{Authors}

Nilay Chakraborty, Michael A. Menze, Heidi Elmoazzen, Halong Vu, Martin L. Yarmush, Steven C. Hand, and Mehmet Toner 


\title{
Trehalose Transporter from African Chironomid Larvae Improves Desiccation Tolerance of Chinese Hamster Ovary Cells
}

\author{
Nilay Chakraborty, $\mathrm{PhD}^{1}$, Michael A. Menze, $\mathrm{PhD}^{3}$, Heidi Elmoazzen, $\mathrm{PhD}^{1}$, Halong Vu, \\ $\mathbf{P h D}^{1}$, Martin L. Yarmush, MD. PhD ${ }^{1,2}$, Steven C. Hand, $\mathbf{P h D}^{4}$, and Mehmet Toner, $\mathbf{P h D}^{1}$ \\ ${ }^{1}$ Center for Engineering in Medicine and BioMEMS Resource Center, Massachusetts General \\ Hospital, Harvard Medical School and Shriners Burn Hospital, Boston, MA, 02114, USA \\ ${ }^{2}$ Department of Biomedical Engineering, Rutgers University, Piscataway, NJ, 00854, USA \\ ${ }^{3}$ Department of Biological Sciences, Eastern Illinois University, Charleston, IL, 61920, USA \\ ${ }^{4}$ Division of Cellular, Developmental, and Integrative Biology, Department of Biological Sciences, \\ Louisiana State University, Baton Rouge, LA, 70803, USA
}

\begin{abstract}
Dry preservation has been explored as an energy-efficient alternative to cryopreservation, but the high sensitivity of mammalian cells to desiccation stress has been one of the major hurdles in storing cells in the desiccated state. An important strategy to reduce desiccation sensitivity involves use of the disaccharide trehalose. Trehalose is known to improve desiccation tolerance in mammalian cells when present on both sides of the cell membrane. Because trehalose is membrane impermeant the development of desiccation strategies involving this promising sugar is hindered. We explored the potential of using a high-capacity trehalose transporter (TRET1) from the African chironomid P. vanderplanki [21] to introduce trehalose into the cytoplasm of mammalian cells and thereby increase desiccation tolerance. When Chinese Hamster Ovary cells (CHO) were stably transfected with TRET1 (CHO-TRET1 cells) and incubated with $0.4 \mathrm{M}$ trehalose for $4 \mathrm{~h}$ at $37^{\circ} \mathrm{C}$, a seven-fold increase in trehalose uptake was observed compared to the wild-type $\mathrm{CHO}$ cells. Following trehalose loading, desiccation tolerance was investigated by evaporative drying of cells at $14 \%$ relative humidity. After desiccation to $2.60 \mathrm{~g}$ of water per gram dry weight, a $170 \%$ increase in viability and a $400 \%$ increase in growth (after 7 days) was observed for CHO-TRET1 relative to control CHO cells. Our results demonstrate the beneficial effect of intracellular trehalose for imparting tolerance to partial desiccation.
\end{abstract}

\section{Introduction}

Current techniques for long-term preservation of mammalian cells depend on cryogenic temperatures and have many disadvantages including complicated procedures, high cost of maintenance and limited transportation ability $[1,3]$. Preservation of biological materials in the dry state at ambient temperature is an alternative approach to address the growing demand for cell replacement technologies and regenerative medicine. However, mammalian

(C) 2011 Elsevier Inc. All rights reserved.

Address for reprint requests and other correspondence: M. Toner; N. Chakraborty Center for Engineering in Medicine and BioMEMS Resource Center, Massachusetts General Hospital, 51 Blossom Street, Boston, MA 02114. Tel.: 617-724-5336; Fax: 617-724-2999; mtoner@hms.harvard.edu; chakraborty.nilay@mgh.harvard.edu.

Publisher's Disclaimer: This is a PDF file of an unedited manuscript that has been accepted for publication. As a service to our customers we are providing this early version of the manuscript. The manuscript will undergo copyediting, typesetting, and review of the resulting proof before it is published in its final citable form. Please note that during the production process errors may be discovered which could affect the content, and all legal disclaimers that apply to the journal pertain. 
cells are highly sensitive to desiccation stresses and the viability of cells decrease rapidly upon drying. Recent research has focused on learning from the adaptive strategies displayed by species that are naturally desiccation tolerant in an attempt to biomimic these in mammalian cells $[22,23]$.

Many anhydrobiotic organisms in nature are capable of withstanding extreme desiccation. Examples of such organisms include plant seeds, bacteria, yeast, nematodes, and cysts of certain crustaceans [10,29]. Some of these organisms can survive the removal of more than $99 \%$ of their body water [9]. Trehalose is found to accumulate in high concentrations (up to $20 \%$ of the dry weight) in many of these anhydrobiotic organisms during desiccation [11], and it is believed to play a major role in imparting desiccation tolerance to anhydrobiotic organisms at the cellular level $[8,9]$. However, as trehalose is impermeant to mammalian cells, a variety of techniques have been explored in order to find an efficient mechanism to introduce sugars, such as trehalose, into the interior of mammalian cells. These include transfection [15], engineered pores [13, 25], activation of native channels [12], microinjection [14], and endocytosis [18, 24]. Recent studies showed that anhydrobiotic insect larvae utilize specific trehalose transporters during desiccation stresses. The trehalose transporter (TRET1) from the anhydrobiotic larvae of African chironomid, Polypedilum vanderplanki has been isolated and characterized by Kikawada and his coworkers [20, 21].

In this study, the TRET1 was stably expressed in CHO cells (CHO-TRET1) and then trehalose introduced into the cells by simple incubation in a trehalose containing medium. Incubation conditions were optimized for exposure time and trehalose concentration, and intracellular trehalose was quantified using high performance liquid chromatography (HPLC). After partial desiccation, significant increases in viability and growth were observed for CHO-TRET1 cells incubated in trehalose solution relative to control $\mathrm{CHO}$ cells.

\section{Materials and Methods}

\section{Cell Culture}

Chinese hamster ovary cells $(\mathrm{CHO})$ were obtained from the American Type Culture Collection (Manassas, VA) and cultured in Dulbecco's modified Eagle's medium (DMEM) (Gibco Life Trechnologies, Gaithersburg, MD) supplemented with 10\% fetal bovine serum (Atlanta Biologicals, Norcross, GA) and $2 \%$ penicillin-streptomycin $(10 \mathrm{U} / \mathrm{mL}$ penicillin $\mathrm{G}$ and $10 \mathrm{ug} / \mathrm{mL}$ streptomycin sulfate, Gibco). Cultures were maintained at $37^{\circ} \mathrm{C}$, and equilibrated with $10 \% \mathrm{CO}_{2}-90 \%$ air in $25-\mathrm{cm}^{2}$ cell culture T-flasks (Corning Incorporated, NY).

\section{Transfection of $\mathrm{CHO}$ cells with trehalose transporters}

The trehalose transporter (TRET1) expression vector (pPvTRET1-IRES2-AcGFP1) for mammalian cell expression was kindly provided by Dr. Takahiro Kikawada from National Institute of Agrobiological Sciences at Ibaraki, Japan. The TRET1 sequence was fused with a green fluorescent protein (GFP) tag at the C-terminus by subcloning into the vector pIRES2-AcGFP1 (Clonetech, Mountain View, CA) for the generation of a stable cell line (pPvTRET1-IRES2-AcGFP1). Wild-type CHO cells were transfected with pPvTRET1IRES2-AcGFP1 using Lipofectamin 2000 and stably transfected cells were selected using Geneticin (Invitrogen, Carlsbad, CA) until colonies of drug resistant cells appeared in the culture dishes. 


\section{Optimization of Trehalose Loading}

When cells reached about $80 \%$ confluence, the cell culture medium in the tissue culture flask was removed completely using a Pasteur pipette with vacuum aspirator and immediately replaced with culture media that was supplemented with 100, 250 and $400 \mathrm{mM}$ trehalose. Cells were then incubated for 1, 2 and $4 \mathrm{~h}$ under the incubation conditions describe above. Cells were then detached from the tissue culture flasks by trypsinization ( $0.25 \%$ trypsin, $1 \mathrm{mM}$ EDTA solution) and collected by centrifugation at $100 \mathrm{~g}$ for $10 \mathrm{~min}$. The cell samples were washed three times in phosphate buffered saline (PBS), and then lysed by freeze-thawing in $18 \mathrm{mOhm}$ high-purity water. The solution containing lysed cells was centrifuged, and the supernatant was collected and filtered for high performance liquid chromatography analysis. Analyses were performed using a Dionex HPLC system with a GP-50 gradient pump, an EC50 electrochemical detector and a PA10 column (Dionex, Sunnyvale, CA). An AS50 auto-sampler and thermal compartment was used for sample handling and injection during analysis. Sample peaks were identified by comparison of retention times to standards, and calibration curves were linear over the range assayed $\left(\mathrm{r}^{2}=\right.$ 0.92). Kinetic analysis of trehalose uptake into the intracellular space was performed at multiple external trehalose concentrations to determine the affinity of TRET1. Data were analyzed using Sigma Plot 12 Enzyme Kinetics Module (Systat Software Inc., IL).

\section{Drying Protocol}

Samples were prepared for dry processing by plating CHO and CHO-TRET1 cells onto 22$\mathrm{mm}$ glass coverslips (Fisher Scientific, Pittsburgh, PA) in $20 \mu \mathrm{l}$ droplets, at a density of $5 \times$ $10^{5}$ cells $/ \mathrm{ml}(10,000$ cells per droplet). The coverslips were then placed in $35 \mathrm{~mm}$ tissue culture dishes (BD Biosciences, Research Triangle Park, NC) and returned to the incubator for $45 \mathrm{~min}$ to allow cell attachment. Following the incubation period, the media was gently aspirated and an equal volume of drying buffer ( $200 \mathrm{mM}$ trehalose, $120 \mathrm{mM} \mathrm{NaCl}, 10 \mathrm{mM}$ $\mathrm{KCl}, 5 \mathrm{mM}$ glucose, $20 \mathrm{mM}$ HEPES, $\mathrm{pH}$ 7.4) was placed on top of the plated cells. These coverslips were then weighed and placed in a Secador autodesiccator (Fisher Scientific, Pittsburgh, PA) for various time durations ranging from 10 to $120 \mathrm{~min}$. A wide range of drying times was used to ensure that a fairly large range of water contents could be measured over the course of a single experiment. The moisture content of the samples were determined gravimetrically, and expressed as a ratio of remaining water mass in the sample to the anhydrous dry weight $\left(\mathrm{gH}_{2} \mathrm{O} / \mathrm{g}\right.$ dry weight). The anhydrous dry weight was measured after baking 5 representative samples at $110{ }^{\circ} \mathrm{C}$ for at least $24 \mathrm{~h}$.

\section{Cell Rehydration and Membrane Integrity Assessment}

Following desiccation, samples were rehydrated using $100 \mu 1$ of cell culture medium and allowed to recover for 20 minutes at $37{ }^{\circ} \mathrm{C}$ and $5 \% \mathrm{CO}_{2}$. After the recovery period the supernatant was carefully removed (leaving behind the cells which were attached to the surface of the cover slip) and the membrane integrity of detached cells was determined by staining with $0.4 \%$ Trypan Blue solution (Fisher Scientific, Pittsburgh PA). The membrane integrity of the attached cells was determined using a SYTO 13 and propidium iodide membrane-integrity assay (Molecular Probes, Eugene, OR). The stock solution was prepared by adding $10 \mu \mathrm{l}$ of a $1 \mathrm{mg} / \mathrm{ml} \mathrm{SYTO} 13$ solution (aq.) and $5 \mu 1$ of a $1.0 \mathrm{mg} / \mathrm{ml}$ propidium iodide solution (aq.) to $10 \mathrm{ml}$ of phenol-red and FBS free DMEM (Invitrogen Corporation, Carlsbad, CA). An aliquot of $130 \mu 1$ of this solution was then added to the attached cells on the coverslip and imaged using an inverted Zeiss microscope (Thornwood, NY) equipped with a dual fluorescence filter set (51004-V2, Chroma Technology, Brattleboro, VT). The membrane integrity of the attached cells was determined by counting the live (green) and dead (red) cells on three representative images from the same sample. The total membrane integrity was estimated by taking in account both detached cells and attached cells (for further details, cf. Chakraborty et al. [5]). 


\section{Long-term Growth Studies}

Following rehydration, the cells were transferred to a $60 \mathrm{~mm}$ cell culture dish (Corning Incorporated, Corning, NY) and cultured for 7 days. Cell counts were performed in parallel samples on the $1^{\text {st }}, 3^{\text {rd }}$ and $7^{\text {th }}$ day of incubation following rehydration $(n=5)$. Cells were collected by trypsinization and were counted in a hemocytometer (Fisher Scientific, Pittsburgh PA), using $0.4 \%$ Trypan Blue (Sigma-Aldrich, St. Louis, MO) exclusion as an indicator of membrane integrity and viability.

\section{Colony Forming Unit Assays}

Proliferation of desiccated cells was studied by measuring clonogenic output by counting colony-forming units (CFU). Desiccated cell samples were rehydrated using fully complemented medium at $37^{\circ} \mathrm{C}$. After a $24 \mathrm{~h}$ recovery period on glass slides, the cells were trypsinized, counted, and approximately 1000 cells $/ \mathrm{mL}$ were transferred to $60 \mathrm{~mm}$ culture plates for colony studies. All samples were cultured at $37^{\circ} \mathrm{C}$ in humidified air containing $10 \% \mathrm{CO}_{2}$ for 7 days, after which colonies were fixed using $3.7 \%$ paraformaldehyde (PFA) solution and stained using $0.05 \%$ crystal violet in distilled water for $30 \mathrm{~min}$. The cell culture dishes were then photographed and colonies enumerated using an inverted Zeiss microscope ( 1 colony contains a minimum of 50 cells).

\section{Results}

CHO cells stably expressing a GFP-labeled trehalose transporter from the African chironomid $P$. vanderplanki (Fig 1B) are morphologically indistinguishable from wild type CHO cells (Fig. 1A). The micrographs were taken at the same stage of confluency and the GFP tagged transporters are visible in the fluorescence micrograph while no such fluorescence was observed in wild type CHO cells (Fig. 1A). HPLC analysis was performed on cell extracts after incubation for different time periods with various extracellular trehalose concentrations. Incubation of the CHO-TRET1 cells in $400 \mathrm{mM}$ trehalose solution for $4 \mathrm{~h}$ resulted in an uptake of $23.45 \pm 2.67 \mathrm{mM}$ trehalose into the cells (Fig. 2A). The intracellular trehalose concentration was estimated using the average volume of the $\mathrm{CHO}$ cells $\left(696.56 \mu \mathrm{m}^{3}\right)$ and considering $70 \%$ of the cell volume to be osmotically active. Figure 2B demonstrates a correlation between the concentration of intracellular trehalose and the viability of the cells. As the data indicate, the increased extracellular osmolality of $400 \mathrm{mM}$ trehalose in the cell culture medium was well tolerated by the cells, and cell viability did not decrease appreciably. However, when the cells were exposed to $600 \mathrm{mM}$ trehalose for $6 \mathrm{~h}$, $\sim 40 \%$ of the cell population lost their viability (data not shown).

Kinetic analysis was used to characterize trehalose uptake into the intracellular space. Assuming one binding site per transporter, the apparent values for $K_{m}$ and $V_{\max }$ were found to be $137 \pm 87 \mathrm{mM}$ and $192 \pm 44 \mathrm{pmol} / \mathrm{min} / 10^{6}$ cells, respectively (Fig. 3). The rather high $K_{m}$ for trehalose indicates low affinity for substrate binding.

After trehalose loading, cells were dried in a low humidity chamber for various time durations to achieve a wide range of final moisture contents. The fraction of $\mathrm{CHO}$ cells that were able to preserve their membrane integrity following rehydration is shown in Figure 4, and expressed as a function of moisture content $\left(\mathrm{gH}_{2} \mathrm{O} / \mathrm{gdw}\right)$. CHO-TRET1 cells incubated in $0.4 \mathrm{M}$ trehalose solution for $4 \mathrm{~h}$ were able to withstand a greater degree of moisture loss than untreated cells $(F=215.45, p<0.05)$ and CHO-TRET1 cells that were not loaded with trehalose showed moisture-dependent decreases in membrane integrity similar to the wildtype $\mathrm{CHO}$ cells (data not shown). Defining $\mathrm{LD}_{50}$ as the degree of dryness that causes half of the initial cell population to lose membrane integrity (indicator of lethality), CHO-TRET1 cells pre-treated with trehalose had a $\mathrm{LD}_{50}$ of $\sim 1.9 \mathrm{gH}_{2} \mathrm{O} / \mathrm{gdw}$, whereas cells that were not 
pre-treated with trehalose had a $\mathrm{LD}_{50}$ of $\sim 4 \mathrm{gH}_{2} \mathrm{O} / \mathrm{gdw}$. Thus CHO-TRET1 cells pre-treated with trehalose can tolerate twice the level of dryness than the cells that were not loaded with trehalose. The membrane integrity of the trehalose-loaded CHO-TRET1 cells gradually decreased until the moisture content of the sample reached $2 \mathrm{gH}_{2} \mathrm{O} / \mathrm{gdw}$. Below this moisture level, the membrane integrity of the cells decreased rapidly. CHO cells that were not pre-treated with trehalose and dried to moisture contents of $4.32 \pm 0.73$ and $3.5 \pm 0.17$ $\mathrm{gH}_{2} \mathrm{O} / \mathrm{gdw}$, showed membrane integrities of $38.66 \pm 2.75$ and $22.9 \pm 2.8 \%$ (mean $\pm \mathrm{SE}, n=$ 5), respectively. $\mathrm{CHO}$ and CHO-TRET1 cells pre-treated with $400 \mathrm{mM}$ trehalose for $4 \mathrm{~h}$ and dried to $4.32 \pm 0.73 \mathrm{gH}_{2} \mathrm{O} / \mathrm{gdw}$ showed membrane integrities of $57.8 \pm 8.7 \%$ and $76.9 \pm 8.3$ $\%$, respectively.

The long-term survival of trehalose - loaded cells following desiccation was indicated by fold increase in number of viable cells at different days following rehydration (Fig 5). Viability was quantified for four distinct cell groups having increasing dryness $(8.12 \pm 0.52$, $6.16 \pm 0.33,4.32 \pm 0.73$ and $\left.2.60 \pm 0.52 \mathrm{gH}_{2} \mathrm{O} / \mathrm{gdw}\right)$. Cell viability was quantified on days 1,3 and 7 . The fractional increase in cell number was compared to non-desiccated control cells. CHO-TRET1 cells outperformed wild type $\mathrm{CHO}$ cells under all conditions investigated. Under most conditions, the difference in growth pattern between CHO-TRET1 cells and the CHO cells become prominent by day $3(72 \mathrm{~h})$. After 7 days of growth under normal culture conditions, the CHO-TRET1 samples desiccated to $2.60 \mathrm{gH}_{2} \mathrm{O} / \mathrm{gdw}$ exhibited almost a four-fold increase in number of cells compared to $\mathrm{CHO}$ samples. However, at higher moisture contents of 4.32, 6.16 and $8.12 \mathrm{gH}_{2} \mathrm{O} / \mathrm{gdw}$ the relative fractional increases in number of cells were lower with 2.5, 1.5 and 1.6, respectively. Colony forming ability was assessed for desiccated samples of CHO-TRET1 and CHO cells to investigate their ability to proliferate following rehydration. Colony counts show a significant difference in number of CFUs between CHO-TRET1 and CHO cells desiccated to 4.32 and $6.16 \mathrm{gH}_{2} \mathrm{O} / \mathrm{gdw}$ (Fig. 6). While CHO-TRET1 cells containing intracellular trehalose demonstrated some colony forming ability (CFU count $1.3 \pm 1.5, n=3$ ) when desiccated to moisture contents of $2.60 \mathrm{gH}_{2} \mathrm{O} / \mathrm{gdw}$, CHO cells under similar conditions (incubated in trehalose solution prior to desiccation) failed to demonstrate any colony growth (data not shown). There was no significant difference in CFU counts between $\mathrm{CHO}$ and CHO-TRET1 control cells (never desiccated) cultured under normal conditions (data not shown). In summary, these data indicate that CHO-TRET1 cells containing intracellular trehalose were able to withstand desiccation stress better compared to control CHO cells.

\section{Discussion}

Transgenic expression of TRET1 from P. vanderplanki has been shown to facilitate transport of trehalose into Xenopus oocytes [21]. In the present study, our objective was to study whether desiccation tolerance of mammalian cells can be improved by taking advantage of the trehalose transport ability of TRET1. The loading characteristics of trehalose into the $\mathrm{CHO}$ cells expressing TRET1 transporters were determined by incubating the cell samples in different concentrations of trehalose solutions. The uptake data were then fitted to the Michaelis-Menten and Eadie-Hofstee equations to provide insight into the nature of the uptake mechanism (Fig. 3). The data show that trehalose uptake was influenced by (a) length of incubation and (b) concentration of trehalose in the incubation solution. Consistent with the findings of Kikawada and his coworkers [21], the $K_{m}$ value for TRET1 in CHO cells was high $(137 \mathrm{mM})$. Since under desiccation stress trehalose accumulates in $P$. vanderplanki in concentrations above $100 \mathrm{mM}$ (Watanabe et al. 2002) the $K_{m}$ value reported here is in good agreement with the naturally occurring concentrations. As previously indicated by Kikawada et al. [21], TRET1 has a low substrate affinity compared to other known sugar transporters in mammalian cells such as GLUT1 ( $\sim 3 \mathrm{mM}$ glucose), GLUT2 ( $\sim 17 \mathrm{mM}$ glucose), and GLUT4 ( 6.6 mM glucose) [26, 27]. 
Incubation of CHO-TRET1 cells in a $400 \mathrm{mM}$ trehalose solution for $4 \mathrm{~h}$ resulted in the intracellular concentrations of approximately $24 \mathrm{mM}$. Such a modest amount of trehalose uptake may be due to suboptimal localization of trehalose transporters in the plasma membrane. However, evidence for successful localization of the TRET1 transporter to the plasma membrane is demonstrated by our positive functional data (increase in viability after desiccation and rehydration), and the data provided by Kikawada et al. [21]. Studies by Chen et al. [7] and Acker et al. [2] indicate that to recover reasonable membrane integrity of the cells after drying below $5 \%$ of moisture content, the intracellular concentration of trehalose has to be more than $0.2 \mathrm{M}$. We were unable to achieve this level of intracellular trehalose in the present study, which could be due to low expression levels of this insect TRET1 in our mammalian cells. Studies are currently underway to optimize the expression of trehalose transporters, which will include modification of the TRET1 DNA sequence to correct for mammalian codon bias.

The process of loading trehalose with TRET1 did not appear to have any adverse effect on the viability of the cells (Fig. 2B). Some procedures for loading sugar, including activation of native channels, permeabilisation of the cell membrane by porating agents and microinjection, have been known to reduce pre-desiccation viability of the cells [12, 13, 14]. Clearly, the absence of any adverse loading effect is an advantage of using the TRET1 transporter.

Ma et al. [22] utilized endocytic loading of trehalose to improve desiccation tolerance of $293 \mathrm{H}$ human embryonic kidney cells. When air-dried to $3.5 \mathrm{gH}_{2} \mathrm{O} / \mathrm{gdw}$ the study reported cell viabilities of $\sim 70 \%$ in presence of $40 \mathrm{mM}$ intracellular trehalose and $\sim 45 \%$ if cells were not loaded with the sugar. $\mathrm{CHO}$ cells that were incubated for $4 \mathrm{~h}$ at $400 \mathrm{mM}$ trehalose presumably also show some endocytotic uptake of the sugar. When desiccated to a moisture content of $4.32 \pm 0.73 \mathrm{gH}_{2} \mathrm{O} / \mathrm{gdw}$ membrane integrity increased from $\sim 50 \%$ in $\mathrm{CHO}$ cells to over $70 \%$ in CHO-TRET1 cells. This indicates a clear advantage of using a transportermediated trehalose loading technique for this cell type. Cell type specific sensitivities to desiccation, different drying conditions, and the amount of intracellular trehalose may be some of the factors responsible for the differences in desiccation response among cell types. While membrane integrity of cells is an early indicator of cell survival, some of the cellular damages resulting from desiccation stress can take hours to days to manifest themselves. Similar to other studies (e.g., Acker et al. [2]), we performed long-term growth experiments to investigate proliferation capacities of CHO-TRET1 and CHO cells after desiccation (Fig. 5). Intracellular trehalose introduced by TRET1 improves long-term growth and survival of CHO-TRET1 cells compared to wild-type CHO cells (Fig. 6).

It is important to note that cellular protection by trehalose against damage incurred during desiccation is not the only mechanism at the disposal of anhydrobiotic organisms. Polypeptides such as late embryogenesis abundant (LEA) proteins are used by many anhydrobiotic organisms $[4,6,16,17]$. It has been suggested that LEA proteins work alongside trehalose in anhydrobiotic organisms, and both may be useful for improving desiccation tolerance in mammalian cells [19].

\section{Conclusion}

Protection of cells using intracellular trehalose is an integral part of any dry preservation strategy for mammalian cells. Our study demonstrates that loading trehalose into cells with TRET1 improves survival of $\mathrm{CHO}$ cells during desiccation. 


\section{Acknowledgments}

This work was supported by National Institutes of Health grants 2 RO1 DK046270-14A1 and 5 R01 GM086886. We thank Dr. Takahiro Kikawada at National Institute of Agrobiological Sciences, Ibaraki, Japan for providing us with the trehalose transporter. We thank Dr. Alireza Abazari for helpful discussions.

\section{Reference}

1. Acker, JP.; Chen, T.; Fowler, A.; Toner, M. Life in Frozen State. Fuller, B.; Lane, N.; Benson, E., editors. Boca Raton FL: CRC Press; 2004. p. 563-580.

2. Acker JP, Fowler A, Lauman B, Cheley S, Toner M. Cell Preserv. Technol. 2002; 1:129-140.

3. Brockbank, GM.; Taylor, MJ. Advances in Biopreservation. Baust, JG.; Baust, JM., editors. New York: Taylor and Francis; 2007. p. 157-196.

4. Browne J, Tunnacliffe A, Burnell A. Nature. 2002; 416:38-38. [PubMed: 11882885]

5. Chakraborty N, Biswas D, Parker W, Moyer P, Elliott GD. Biotechnol. Bioeng. 2008; 100:782-796. [PubMed: 18318445]

6. Chakrabortee S, Boschetti C, Walton LJ, Sarkar S, Rubinsztein DC, Tunnacliffe A. Proc. Natl. Acad. Sci. U. S. A. 2007; 104:18073-18078. [PubMed: 17984052]

7. Chen T, Acker JP, Eroglu A, Cheley S, Bayley H, Flower A, Toner M. Cryobiology. 2001; 43:168181. [PubMed: 11846471]

8. Crowe JH, Crowe LM, Carpenter JF, Winstorm CA. Biochem. J. 1987; 242:1-10. [PubMed: 2954537]

9. Crowe JH, Carpenter JF, Crowe LM. Annu. Rev. Physiol. 1998; 60:73-103. [PubMed: 9558455]

10. Crowe JH, Hoekstra FA, Crowe LM. Annu. Rev. Physiol. 1992; 54:579-599. [PubMed: 1562184]

11. Crowe JH, Crowe LM. Nat. Biotechnol. 2000; 18:145-146. [PubMed: 10657114]

12. Elliott GD, Liu XH, Cusick J, Menze MA, Witt T, Hand SC, Toner M. Cryobiology. 2006; 52:114-127. [PubMed: 16338230]

13. Eroglu A, Russo MJ, Bieganski R, Flower A, Cheley S, Bayley H, Toner M. Nat. Biotechnol. 2000; 18:163-167. [PubMed: 10657121]

14. Eroglu A, Lawitts JA, Toner M, Toth T. Cryobiology. 2003; 46:121-134. [PubMed: 12686202]

15. Guo N, Puhlev I, Brown DR, Mansbridge J, Levine F. Nat. Biotechnol. 2000; 18:168-171. [PubMed: 10657122]

16. Hand SC, Jones D, Menze MA, Witt TL. J. Exp. Zoology Part A. 2007; 307A:62-66.

17. Hand SC, Menze MA, Toner M, Boswell L, Moore D. Annu. Rev. Physiol. 2011; 73:115-134. [PubMed: 21034219]

18. Hubel A, Darr TB. Cryobiology. 2002; 45:227.

19. Itturiaga G. Biochem. J. 2008; 410:e1-e2. [PubMed: 18254727]

20. Kanamori Y, Saito A, Hagiwara-Komoda Y, Tanaka D, Mitsumasu K, Kikuta S, Watanabe M, Cornette R, Kikawada T, Okuda T. Insect Biochem. Mol. Biol. 2010; 40:30-37. [PubMed: 20035867]

21. Kikawada T, Saito A, Kanamori Y, Nakahara Y, Iwata K, Tanaka D, Watanabe M, Okuda T. Proc. Natl. Acad. Sci. U. S. A. 2007; 104:11585-11590. [PubMed: 17606922]

22. Ma X, Jamil K, Macrae TH, Clegg JS, Russell JM, Villeneuse TS, Euloth M, Sun Y, Crowe JH, Tablin F, Oliver AE. Cryobiology. 2005; 51:15-28. [PubMed: 15963489]

23. Menze MA, Chakraborty N, Clavenna M, Banerjee M, Liu X-H, Toner M, Hand SC. Cryobiology. 2010; 61:79-88. [PubMed: 20510224]

24. Oliver AE, Jamil K, Crowe JH, Tablin F. Cell Preservation Technol. 2004; 2:35-49.

25. Russo MJ, Bayley H, Toner M. Nat. Biotechnol. 1997; 15:278-282. [PubMed: 9062930]

26. Thorens B, Mueckler M. Am. J. Physiol. Endocrinol. Metab. 2010; 298:E141-E145. [PubMed: 20009031]

27. Uldry M, Thorens B. Pflügers Arch. 2004; 447:480-489.

28. Watanabe M, Kikawada T, Minagawa N, Yukuhiro F, Okuda T. J Exp Biol. 2002; 18:2799-2802. [PubMed: 12177145] 
29. Yancey PH, Clark ME, Hand SC, Bowlus RD, Somero GN. Science. 1982; 217:1214-1222. [PubMed: 7112124] 


\section{$\mathrm{CHO}(\mathrm{WT})$}
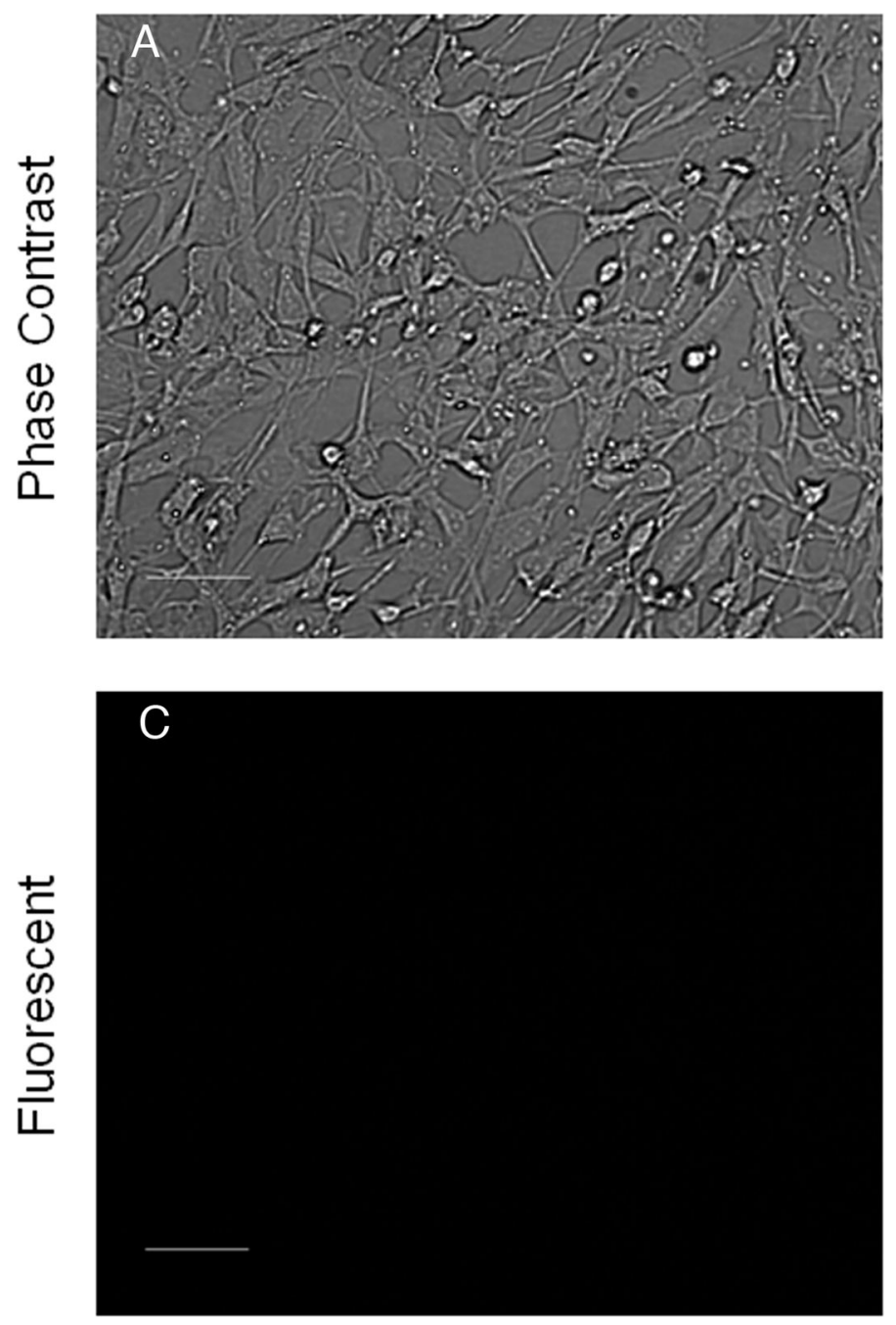

CHO-TRET1
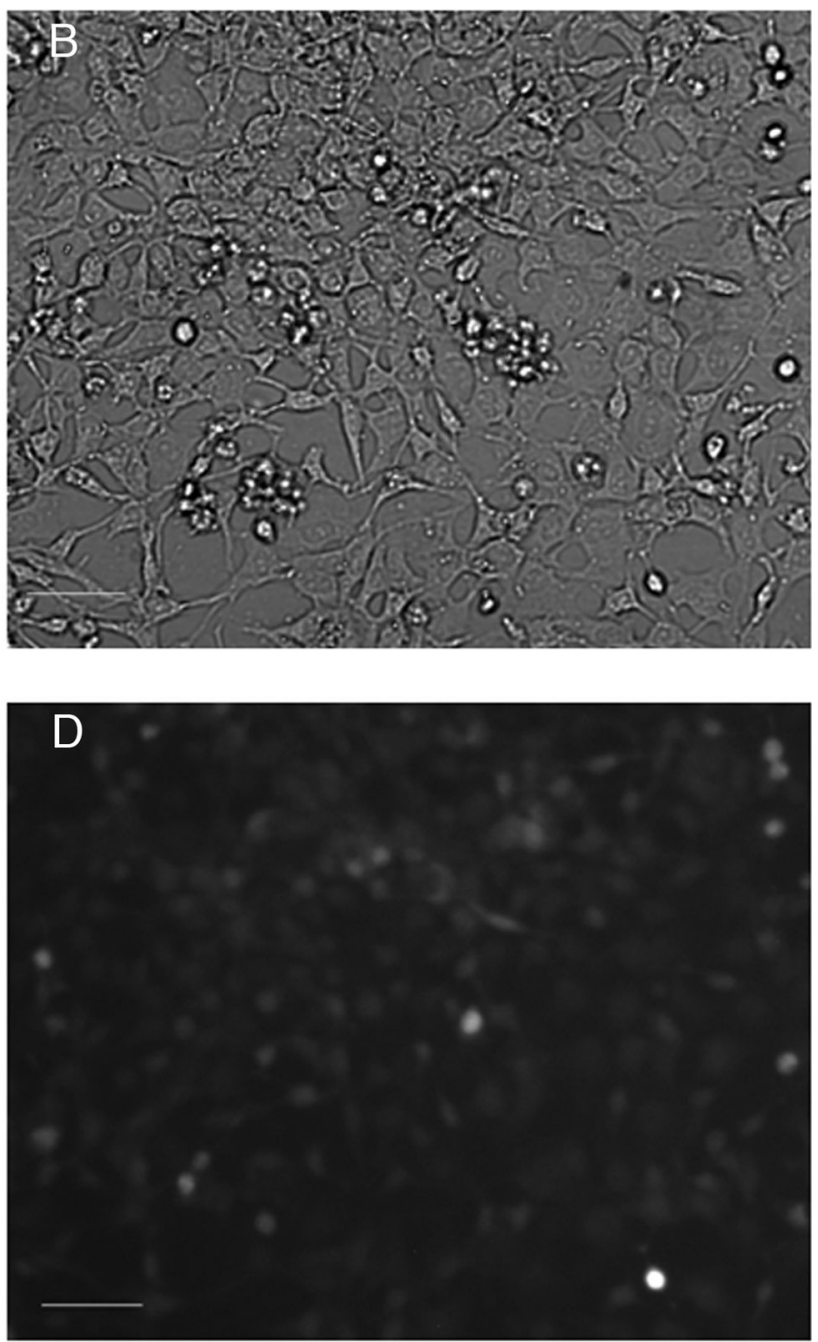

Figure 1.

Micrograph of CHO cells (wild-type and TRET1). The GFP tagged transporters are visible in fluorescence micrograph (wavelength 490nm). The bars in image represent $100 \mu \mathrm{m}$. 
A

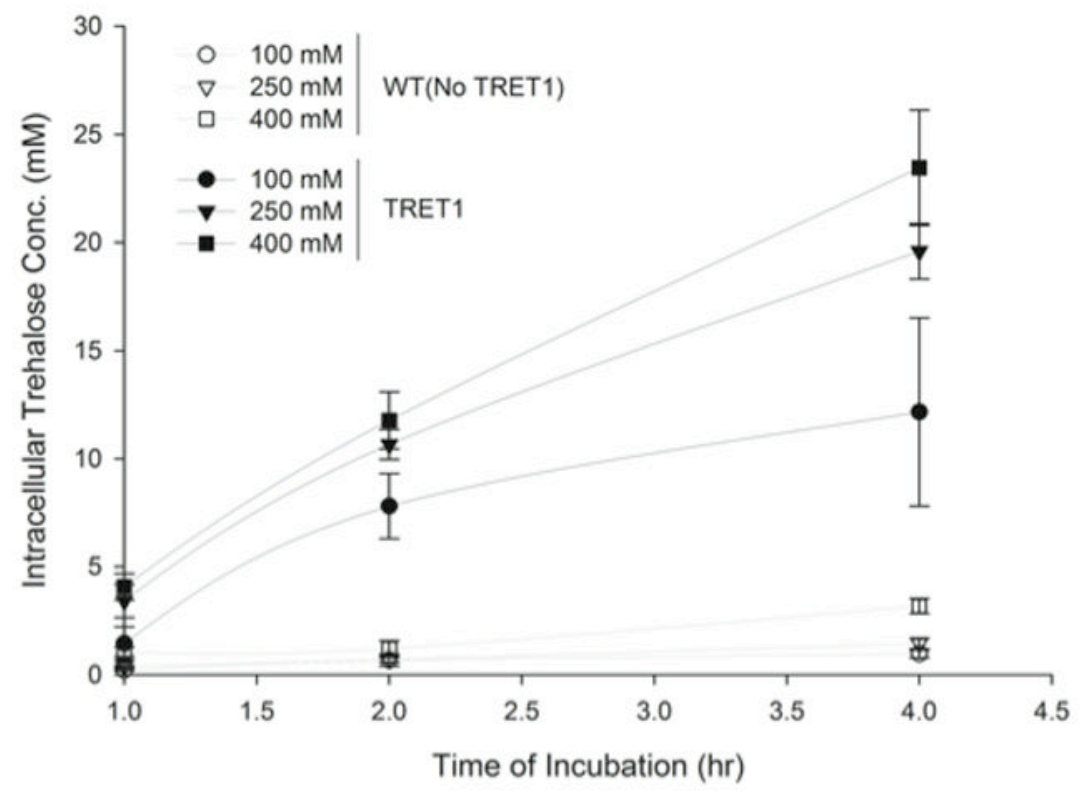

B

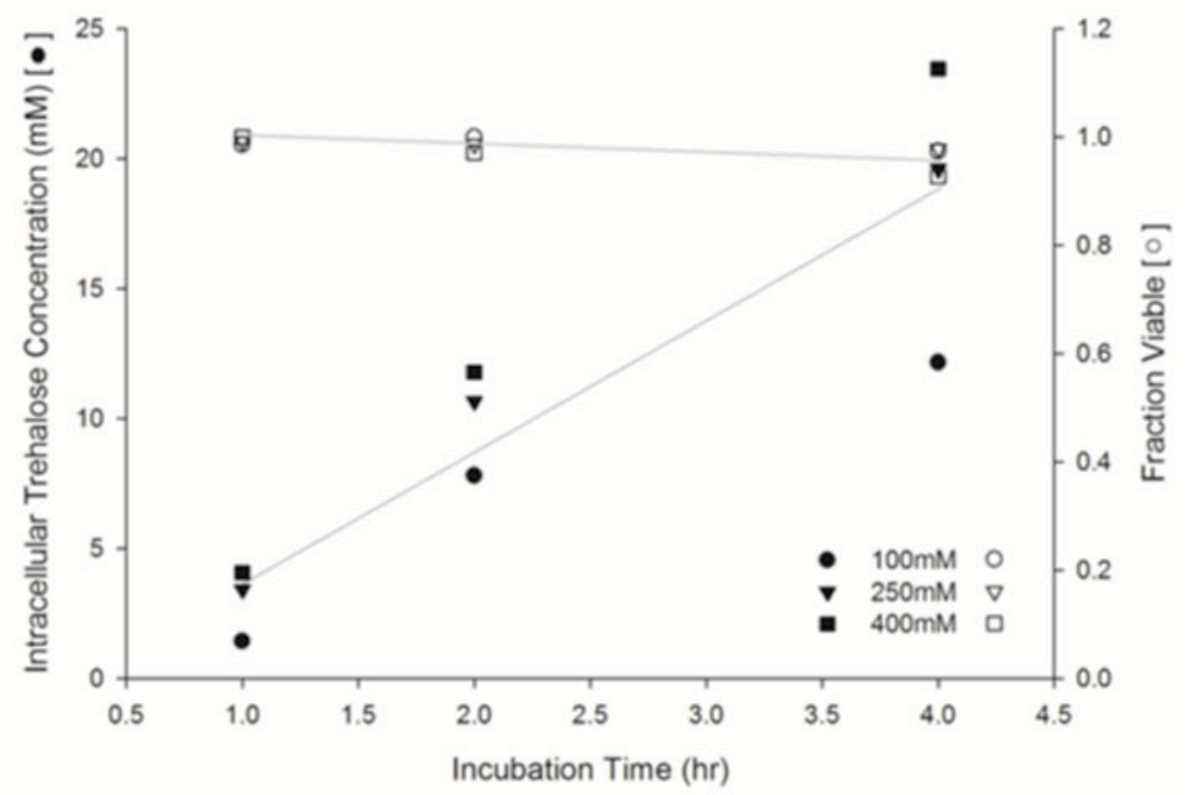

Figure 2.

(A) TRET1 increases trehalose uptake in the CHO cells. The intracellular concentration of trehalose was quantified using HPLC. Both transfected and wild-type CHO cells were incubated in cell culture medium containing 100, 250 and $400 \mathrm{mM}$ trehalose for 1, 2 and 4 h. Each value is the mean $+/-\mathrm{SD}(n=3)$. (B) Membrane integrity and intracellular trehalose concentration in CHO-TRET1 cells plotted against incubation time. CHO-TRET1 cells were incubated at $37^{\circ} \mathrm{C}$ in cell culture medium having $100-400 \mathrm{mM}$ trehalose for $0-4 \mathrm{~h}$. Error bars are removed for clarity. 


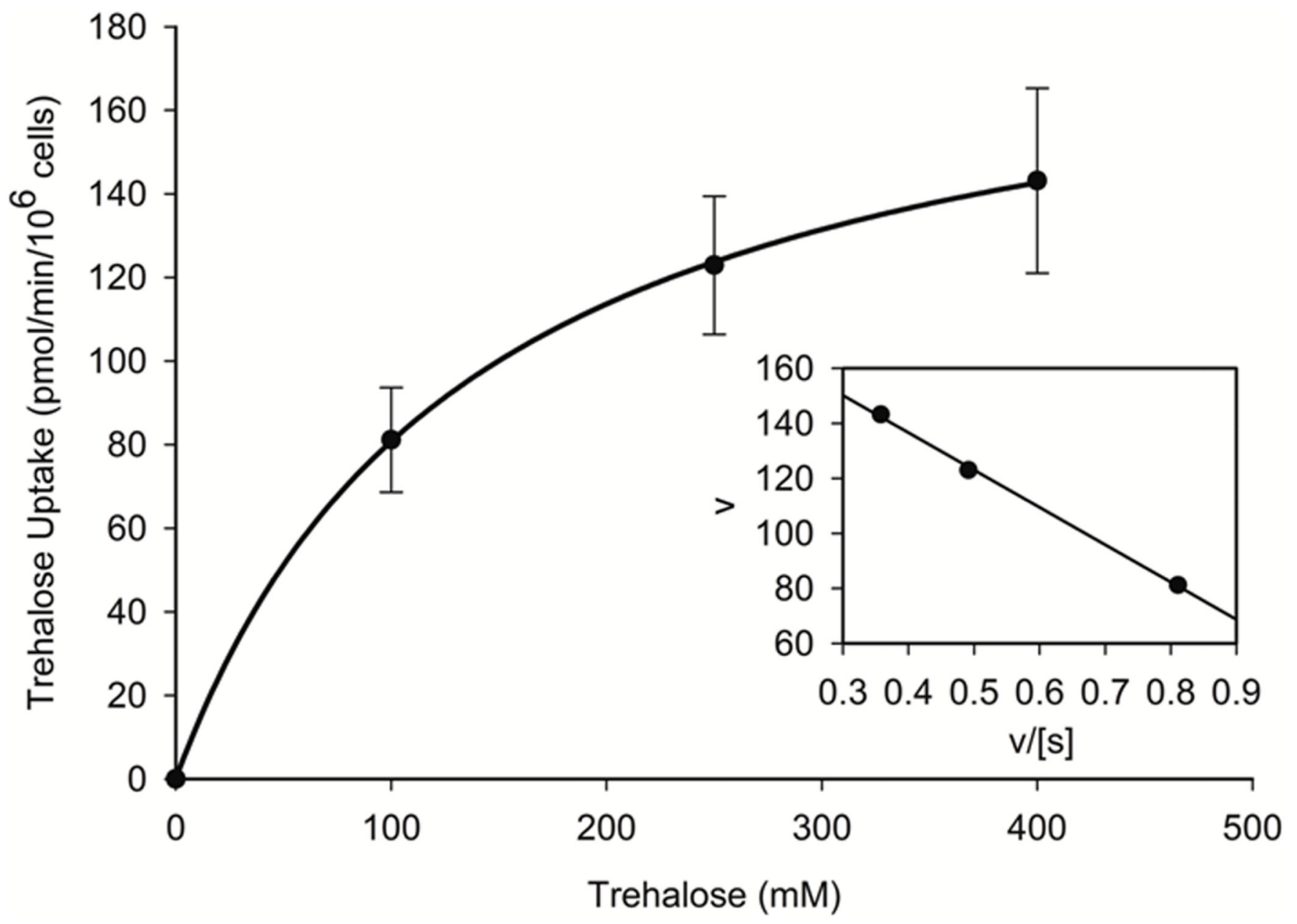

Figure 3.

Kinetics analysis of zero-trans activity of TRET1 transporter for trehalose in CHO cells. CHO cells expressing TRET1 were incubated in various concentrations of trehalose and the uptake data were fitted to the Michaelis-Menten and Eadie-Hofstee (Inset) equations.

Apparent $K_{m}$ and $V_{\max }$ were calculated by nonlinear approximation. Each value is the mean $\pm \mathrm{SE}(n=3)$. 


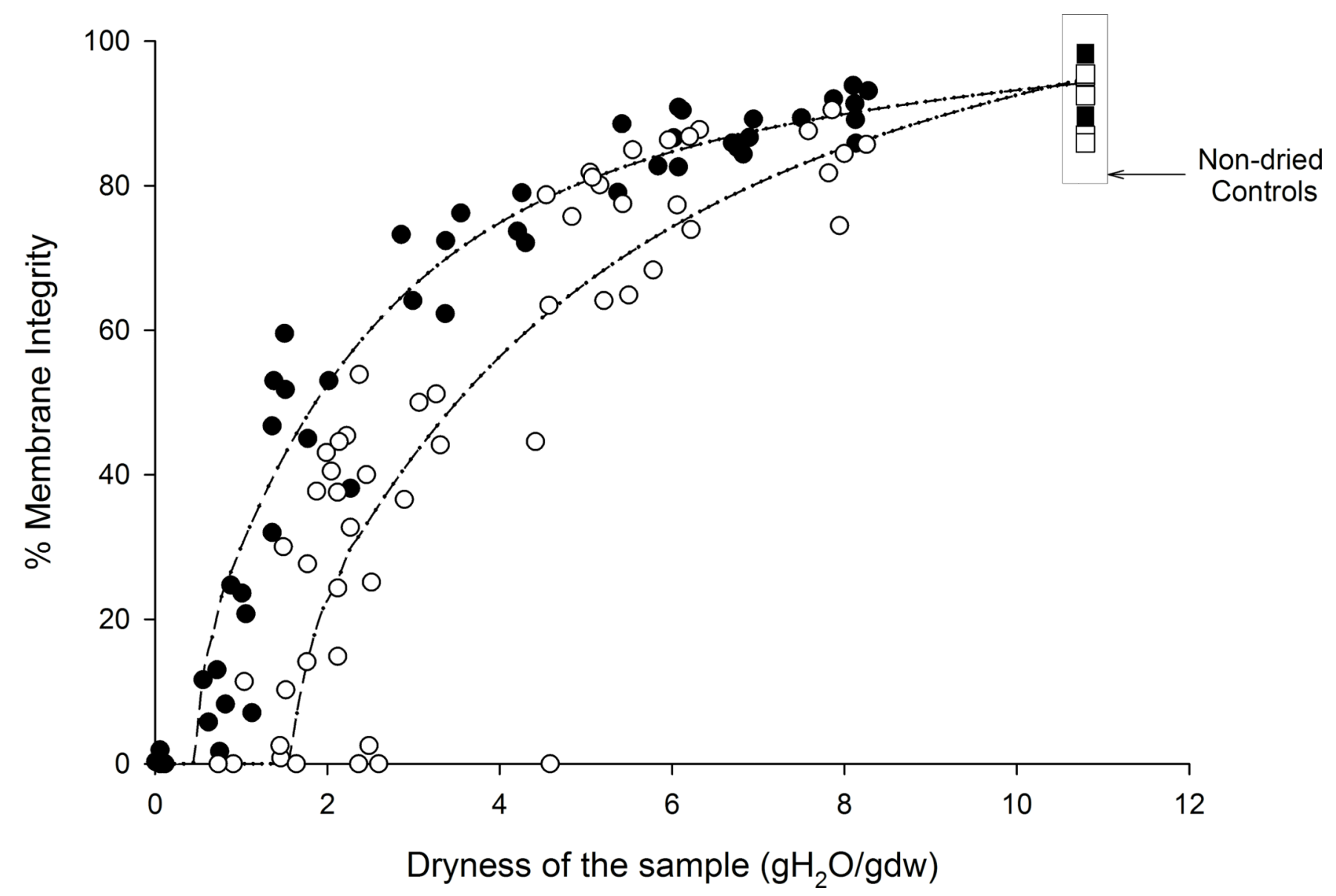

Figure 4.

The viability response of CHO-TRET1 cells (incubated for $4 \mathrm{~h}$ in $400 \mathrm{mM}$ extracellular trehalose solution) compared to $\mathrm{CHO}$ cells (without trehalose transporter) dried to different levels of moisture contents. Viability assessment was performed 45 minutes postrehydration. 
(A)

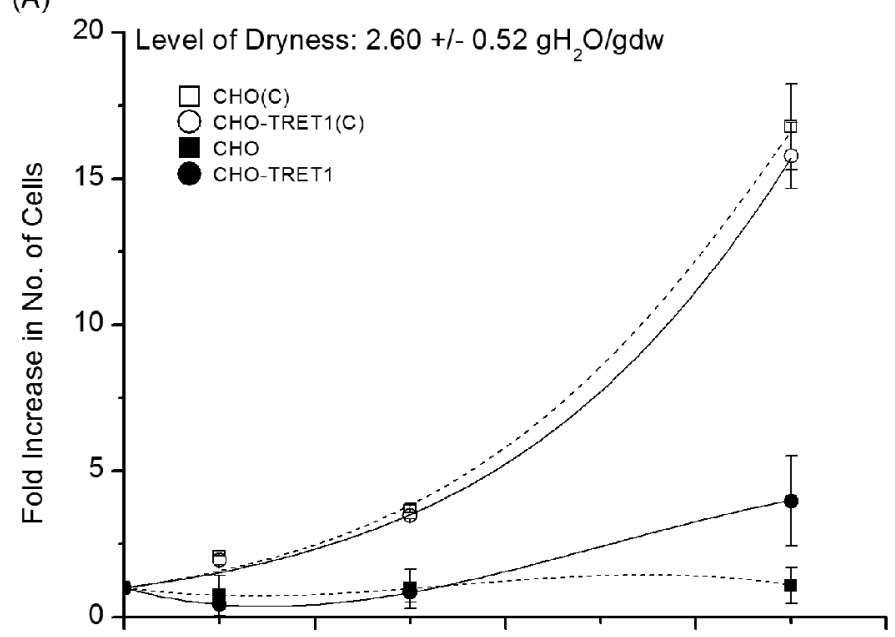

(C)

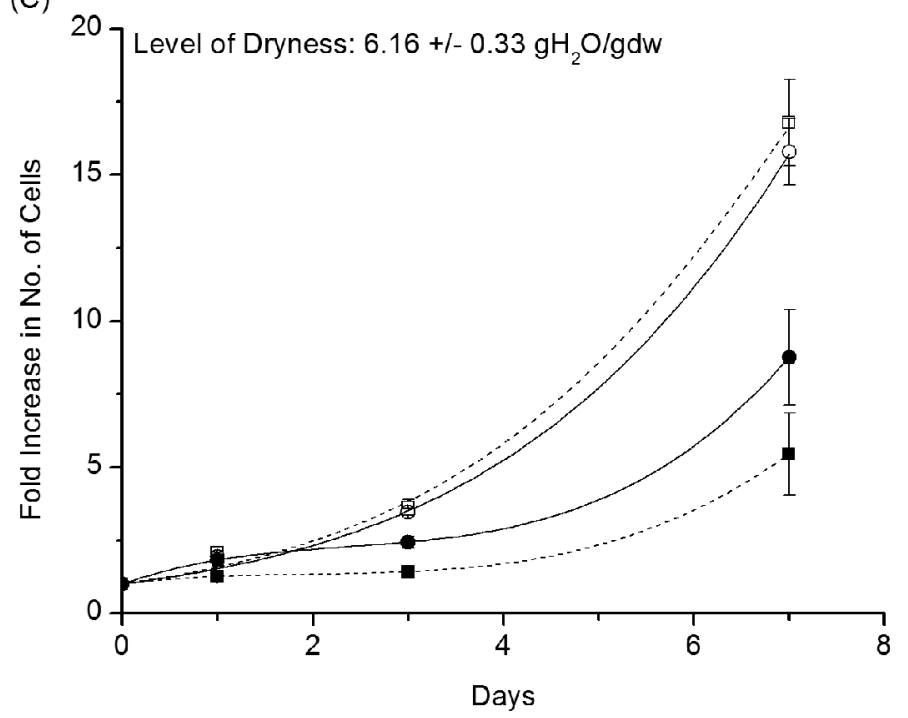

(B)

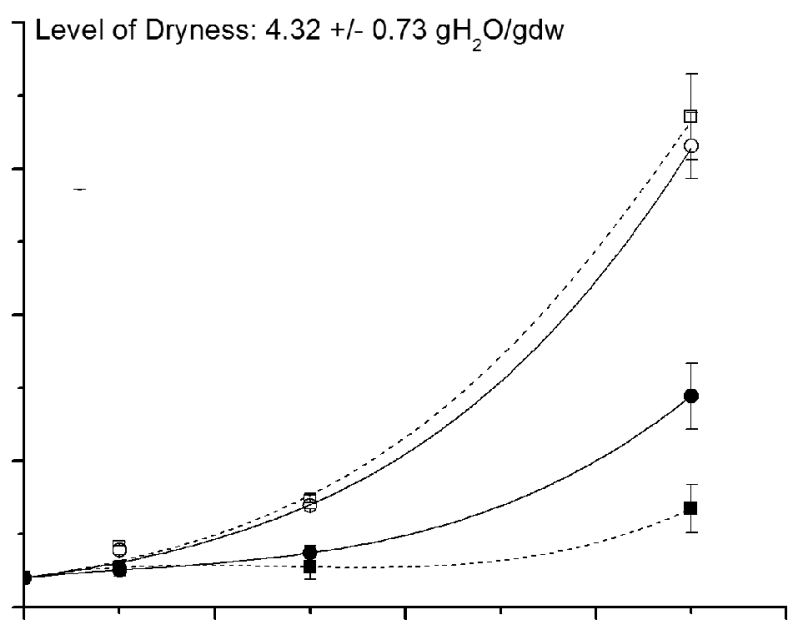

(D)

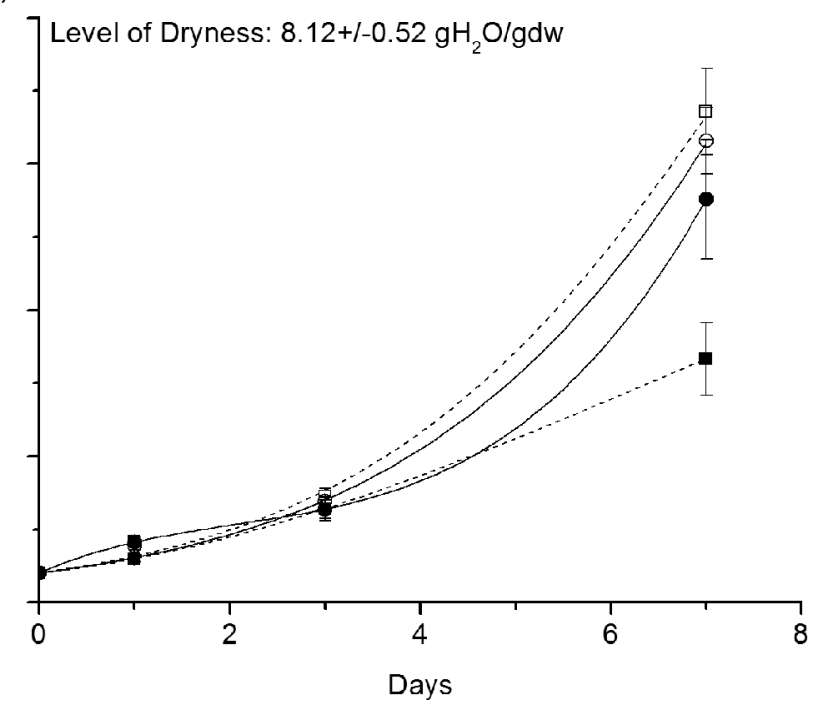

Figure 5.

Survival after drying at day 1, 3 and 7 expressed as fold increase in number of cells in culture for CHO-TRET1 and CHO samples previously dried to the indicated moisture contents. Both CHO-TRET1 and CHO cells were incubated with trehalose before drying. Non-desiccated control cells (labeled 'C') are depicted with open symbols. Error bars represent $\pm \mathrm{SE}(n=7)$. 
(A)

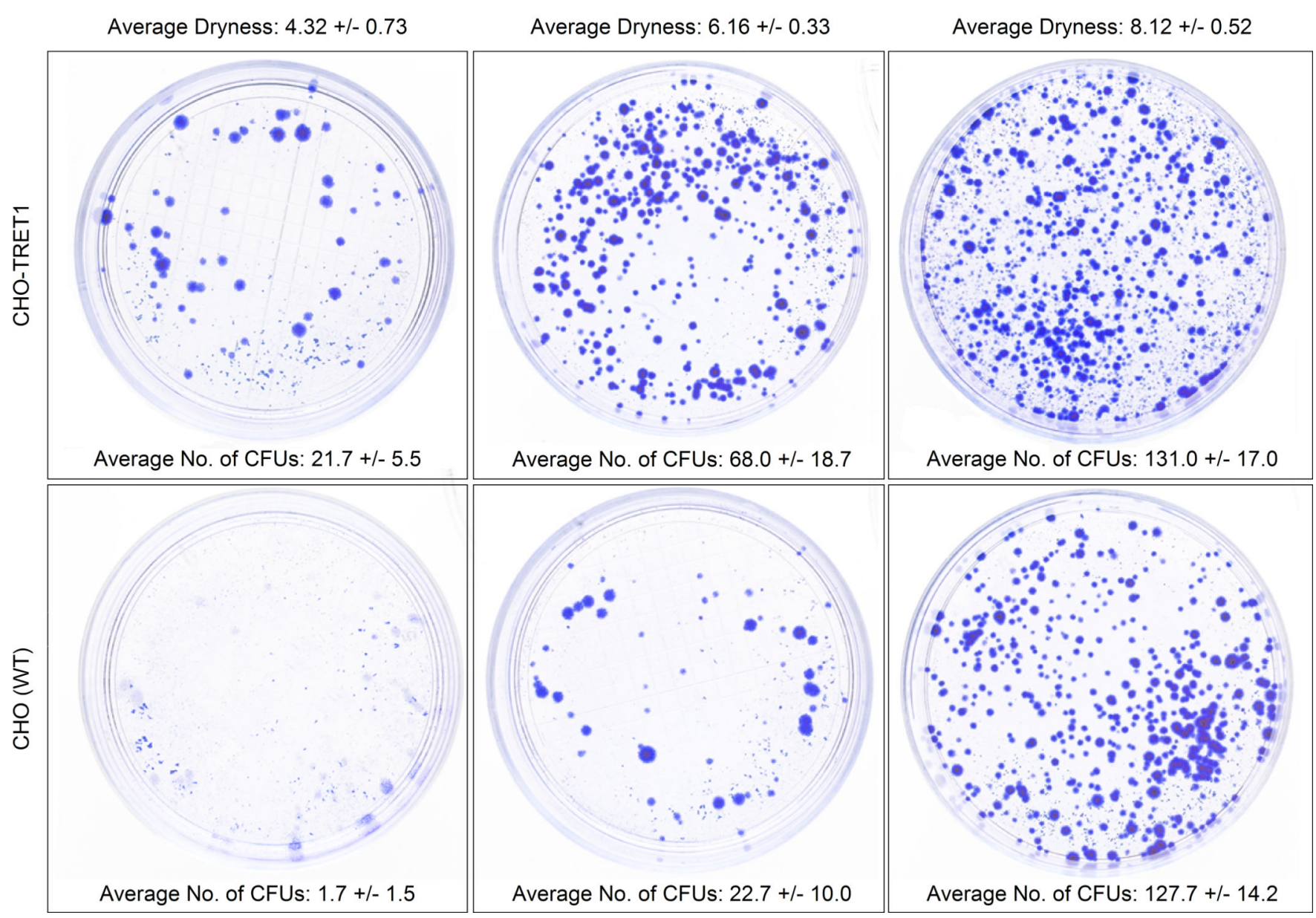

Figure 6.

The colony forming abilities of previously desiccated cell samples incubated under normal culture conditions. Samples (A), (B) and (C) were dried to $4.32 \pm 0.73,6.16 \pm 0.33$ and 8.12 $\pm 0.52 \mathrm{gH}_{2} \mathrm{O} / \mathrm{gdw}$, respectively, and colony forming units (CFUs) were quantified for each of the conditions. 